УДК 378.147

DOI https://doi.org/10.52726/as.pedagogy/2021.3.1.6

\author{
I. М. ГУМЕНЮК \\ кандидат філологічних наук, дочент, \\ дочент кафедри педагогіки початкової освіти, \\ Прикарпатський національний університет імені Василя Стефаника, \\ м. Івано-Франківськ, Україна \\ Електроннапошта: imix@ukr.net \\ http://orcid.org/0000-0002-0790-6732
}

\title{
ФУНКЦІЙНО-СТИЛІСТИЧНИЙ ПІДХІД ДО НАВЧАННЯ УКРАЇНСЬКОЇ МОВИ ЗА ПРОФЕСІЙНИМ СПРЯМУВАННЯМ МАЙБУТНІХ УЧИТЕЛІВ ПОЧАТКОВИХ КЛАСІВ
}

Стаття присвячена вивченню проблеми реалізації функційно-стилістичного підходу у контексті навчання дисципліни «Українська мова за професійним спрямуванням». Дослідження проведено у процесі викладання цього курсу майбутнім учителям початкових класів у Прикарпатському національному університеті ім. В. Стефаника. На основі ретроспективного аналізу еволюційних змін у змісті дисципліни та специфіки професійної діяльності вчителя початкових класів обгрунтовано застосування функційно-стилістичного підходу з акцентом на особливостях кожного стилю у відповідній ситуації спілкування. Авторка розкриває поетапну реалізацію функційно-стилістичного підходу до навчання української мови за професійним спрямуванням, що передбачає дотримання принципів систематичності та поступовості, науковості, наростання складності, забезпечення професійного контексту в навчальній діяльності, зв'язку теорії із практикою. Кожен із визначених етапів проаналізовано щодо ефективних форм організації роботи студентів, комплексів завдань і оцінюваних продуктів навчальної діяльності. Розкрито мотиваційний, діяльнісний і прикладний аспекти стилістичної роботи. Наголошено на необхідності урахування нормативної бази, зокрема професійного стандарту за професією «Вчитель початкових класів закладу загальної середньої освіти», Державного стандарту початкової освіти, чинного ДСТУ 4163-2003. Зазначено, що реалізація аналізованого підходу здійснюється під час опанування як писемних, усних, так і емоційно-експресивних стилів. Для застосування функційно-стилістичного підходу щодо формування наукового мовлення майбутніх педагогів необхідна міждисциплінарна інтеграція, що сприяє комплексному баченню комунікативного середовища професійної сфери. Окремо у стилістичному контексті проаналізовано роботу з особливо обдарованими студентами.

Ключові слова: мовна освіта, професійне мовлення, стиль, термін, компетентність, стилістичне редагування, функційно-стилістичний підхід.

Постановка проблеми. Професійне становлення вчителя початкових класів грунтується на здатності до продуктивного спілкування, підвищеній відповідальності за його результати, методичній підготовці до роботи 3 мовленням школярів. Тому формування професійної мовленнєвої компетентності студентів залежить від вдалої інтеграції підходів до навчання, зокрема застосування у цьому комплексі функційностилістичного підходу, що відображає багатогранність мовленнєвої діяльності педагога.

Українська мова за професійним спрямуванням (далі - УМзаПС) як навчальна дисципліна заснована на грунті ділової української мови, зміст якої розкривав особливості спілкування у діловій сфері, що обслуговується офіційноділовим стилем. Саме тому на етапі становлення цього курсу виникла наукова дискусія щодо однобічності змістового наповнення, розвитку комунікативних умінь студентів тільки у напрямку ділового спілкування [Гуменюк 2020]. Розширення навчальної мети УМзаПС до формування «досконалого володіння українською літературною мовою у фаховій сфері» [Шевчук 2010 : 15] дозволило трансформувати межі поняття «професійна мова» до трьох функціональних стилів: розмовного, офіційноділового, наукового [Шевчук 2010 : 115]. Саме ці три стилістичні різновиди лежать в основі більшості підручників і посібників із УМзаПС. Однак специфіка педагогічної діяльності, зокрема у початковій ланці освіти, актуалізує необхідність роботи в усіх стилях української літературної мови, з урахуванням як писемних, усних, так і емоційно-експресивних різновидів. Відповідно до Державного стандарту 
початкової освіти, формування переліку ключових компетентностей дітей, зокрема «вільне володіння державною мовою», «відчуття краси слова», «активне використання рідної мови в різних комунікативних ситуаціях...», «розуміння правил поведінки і спілкування, що $є$ загальноприйнятими в різних спільнотах i середовищах» [Державний стандарт] тощо, неможливе без ознайомлення з виражальними можливостями мови в усіх стилях, художньому й публіцистичному зокрема. У цьому контексті вважаємо необхідним застосування функційностилістичного підходу до навчання УМзаПС у педагогічних 3ВО з акцентуванням на особливостях кожного стилю у відповідній ситуації спілкування.

Аналіз попередніх досліджень. Внаслідок аналізу інформаційного простору виявлено відсутність науково-методичного інтересу до проблеми реалізації функційно-стилістичного підходу у курсі УМзаПС. За весь період функціонування дисципліни незначна активізація спостерігається 2007-2008 pр. у напрямку дослідження стилістичних особливостей усної ділової комунікації та стилістичних варіантів мовних норм. I. Серебрянська здійснила порівняльно-стилістичний аналіз мовних одиниць українського й англійського ділового спілкування з акцентом на специфіці проведення ділової бесіди. Дослідниця екстраполює методику безперервної рольової гри О. Тарнопольського, розроблену для вивчення англійської мови, на курс «УМзаПС», наголошуючи на моделюванні реальної ділової активності та реалізації творчого потенціалу студентів [Серебрянська 2007], однак уся навчальна діяльність проводиться тільки у межах офіційно-ділового стилю. О. Левківська пропонує систему вправ iз вивчення мовних норм i ïx стилістичних варіантів під час навчання УМзаПС, але пропоновані завдання відображають стилістичні можливості лінгвістичних одиниць здебільшого у межах процесу редагування [Левківська 2008]. Дослідженню шляхів формування стилістичної компетентності студентів присвячена праця А. Нечипоренко. Особливу увагу авторка звертає на порушення стилістичних норм, які ускладнюють досягнення комунікативної мети. Уникнути таких порушень можна, на думку дослідниці, шляхом аналізу та редагування текстів різних стилів [Нечипоренко 2021]. Як бачимо, проблема застосування функційностилістичного підходу до навчання УМзаПС залишається малодослідженою, а 3 урахуванням різноаспектної комунікативної діяльності вчителя початкових класів - актуальною.

Мета дослідження - побудова алгоритму реалізації функційно-стилістичного підходу у контексті навчання української мови за професійним спрямуванням студентів педагогічних закладів вищої освіти.

Виклад основного матеріалу. Реалізація системи роботи з УМзаПС на основі функційно-стилістичного підходу здійснюється поетапно: 1) вивчення специфіки професійного мовлення через дослідження його стилістичних виявів; 2) систематизація нормативних вимог літературної мови з виявленням стилістичних можливостей на кожному рівні мовної системи; 3) диференціація стилістичних різновидів писемної, усної й емоційно-експресивної мови; 4) визначення позиції стилістичних умінь у комунікативній професіограмі вчителя початкових класів; 5) 3'ясування особливостей писемної форми офіційно-ділового стилю через вправляння у складанні й оформленні ділової документації; 6) вивчення особливостей побудови наукового тексту й оформлення результатів наукової діяльності; 7) практичне застосування набутих умінь у процесі редагування текстів різних стилів. Такий етапний розподіл забезпечує дотримання принципів систематичності та поступовості, науковості, наростання складності, забезпечення професійного контексту у навчальній діяльності, зв'язку теорії із практикою.

Форми роботи й комплекс завдань до кожного із зазначених етапів підбираються залежно від його мети. Зокрема, специфіка професійного мовлення з'ясовується шляхом проблемної бесіди: Яким повинно бути мовлення педагога? Які стилі мови використовує вчитель початкових класів у своїй професійній діяльності? Яким стилем ми користуємося зараз? Як ви розумієте поняття «професійно-мовленнєва компетентність»? Як впливає рівень професійно-мовленнєвої компетентності вчителя на його авторитет у педагогічному й учнівському колективах?

Етап систематизації нормативних вимог літературної мови зі стилістичним застосуванням 
не обмежується одним заняттям, що зумовлено кількістю інформації та ії складністю. Елементи такої роботи вводяться у структуру кожного заняття у вигляді вправ або презентації інформаційного проєкту, зокрема теми «Синтаксис професійного мовлення», «Орфоепічні й акцентуаційні норми у мовленні вчителя», «Лексика іншомовного походження у стилістичному плані» та ін. Завдання на правопис вважаємо за необхідне адаптувати до змісту теми. У контексті розгляду вимог до тексту документа доречними будуть вправи на вживання великої літери у найменуваннях організацій, установ, посад, державних свят, подій, у назвах документів, їх структурних частин, пунктуаційне оформлення заголовків, дієприкметникових і дієприслівникових зворотів, вставних і вставлених конструкцій. Оформлення документації з кадрово-контрактних питань і довідково-інформаційних документів вимагає особливої уваги до відмінювання прізвищ, імен, по батькові, орфографічних і технічних правил переносу, пунктуаційного оформлення дат, адрес, графічних скорочень, вживання форм кличного відмінка тощо. Пунктуаційне оформлення засобів передачі чужого мовлення доречним буде під час опанування вимог до наукового тексту, як і вживання прийменникових форм, правопис слів із часткою не, правопис іншомовних слів і прикметників, утворених від географічних назв.

Диференціація стилів відбувається на основі вивчення теоретичного матеріалу щодо сфери використання, форм, призначення і найбільш характерних мовних засобів у кожному із семи писемних стилістичних різновидів, трьох стилів усної мови та трьох стилів, що виокремлюються за емоційно-експресивними ознаками. Функційний аспект реалізується у процесі виконання системи завдань із поступовим наростанням складності: визначення стильової належності усного чи писемного тексту, аналіз тексту за стилістичними ознаками, розподіл лексичних засобів за співвідношенням зі стилем, визначення відтінків значення і стилістичних умов використання слів, корекція стилістично невідповідних текстів, самостійне створення текстів різних стилів.

Мотиваційний аспект стилістичної роботи забезпечується 3'ясуванням позиції стилістичних умінь у комунікативній професіограмі май- бутнього вчителя початкових класів. Втілення кожної вимоги та реалізація особистісних якостей фахівця повинні бути проаналізовані у контексті міжособистісної взаємодії, застосування елементів усіх стилів у професійній діяльності педагога. Результати обговорення доцільно підтвердити нормативними актами. Відповідно до затвердженого 2020 року професійного стандарту за професією «Вчитель початкових класів закладу загальної середньої освіти» необхідне володіння мовно-комунікативною компетентністю, що грунтується на знаннях норм і стилів української літературної мови, здійсненні усної та письмової комунікації під час виконання службових обов'язків [Про затвердження : 10].

Практичне засвоєння особливостей офіційно-ділового стилю у курсі УМзаПС забезпечується роботою з документами як засобами писемної професійної комунікації. На основі чинного ДСТУ 4163-2003 студенти усвідомлюють сутність стандартизації як основної ознаки стилю, використання усталених мовних зворотів, стандартних початків і закінчень, специфічних синтаксичних конструкцій, іншомовних слів і термінів у документах.

Вивчення наукового стилю й особливостей використання його засобів у професійному спілкуванні грунтується на загальному уявленні про термінологію як систему, розумінні сутності поняття «термін», його ознак, класифікації та способів творення. Диференціація загальнонаукової, міжгалузевої та вузькогалузевої термінології здійснюється 3 опорою на майбутню професійну діяльність студентів. Зокрема, до загальнонаукових термінів, володіння якими необхідне майбутнім педагогам, належать: система (мовна система), закон (закони милозвучності), теорія, гіпотеза, аналіз, синтез та ін. Розуміння міжгалузевої специфіки психолого-педагогічних термінів важливе для професійного становлення вчителя початкових класів, наприклад: адаптація, бесіда, здiбності, мотив, мотивація, навіювання, пізнавальні інтереси, спостереження, спілкування, розвиток та ін. Вузькогалузева термінологія $\epsilon$ основою професійного спілкування, тому іiі опанування потребує особливої уваги. У багатьох педагогічних ЗВО дисципліна «УМзаПС» передбачена для вивчення на першому курсі, відповідно у студентів ще не сформована 
термінологічна база. Для реалізації функційно-стилістичного підходу щодо формування наукового мовлення майбутніх педагогів необхідна міждисциплінарна інтеграція, що сприяє комплексному баченню комунікативного середовища професійної сфери.

Вивчення формальної сторони наукового стилю спирається на ознайомлення 3 основними засобами організації результатів наукової діяльності: конспектування, складання простого, складного, питального, номінативного та тезового планів, формулювання тез, анотування і реферування наукових текстів, оформлення покликань і бібліографічного опису джерел. Це обов'язковий мінімум для опанування усіма студентами. Робота 3 особливо обдарованим студентами у стилістичному контексті може бути продовжена у процесі написання наукової статті та іiі публікації. Мотиваційну функцію у цьому виді завдання виконують вибір теми для дослідження (за інтересами студентів, як частина майбутньої курсової чи дипломної роботи, як прикладний аспект для застосування у професійній діяльності), процес публікації та належне оцінювання.

Опанування мовних і структурних особливостей писемних стилів української мови стає підгрунтям для завершального етапу реалізації функційно-стилістичного підходу до навчання УМзаПС - редагування текстів різних стилів із акцентом на професійно-наукових висловлю- ваннях. У цьому процесі необхідно зосередити увагу на типових помилках російсько-українського перекладу, а також найбільш поширених синтаксичних порушеннях. Проведення міжмовних паралелей дозволяє студентам швидше зрозуміти і засвоїти основні випадки недотримання українських мовних норм навіть у тих випадках, коли російська мова не була предметом вивчення. Недотримання студентами стилістики наукового тексту проявляється у необгрунтованому використанні вставних слів, прикметників-епітетів у найвищому ступені порівняння, тавтології, суб'єктивних висловлюваннях тощо. Пошук і виправлення названих недоліків становлять основу завдань на редагування, причому зміст таких завдань може варіюватися залежно від мети: редагування попередньо створених текстів із недоліками, пошук стилістичних похибок у авторських текстах, стилістичне редагування робіт студентів, створення банку найбільш поширених стилістичних недоліків, фотоколаж та ін.

Отже, основні етапи реалізації функційностилістичного підходу до навчання УМзаПС можна відобразити схематично (рис. 1).

Реалізація зазначених на рис. 1 етапів відбувається комплексно, у контексті опанування як писемних, усних, так і емоційно-експресивних стилів української мови. Особливості ораторського стилю студенти засвоюють практично, під час усних відповідей, бесід, презентації проєк-

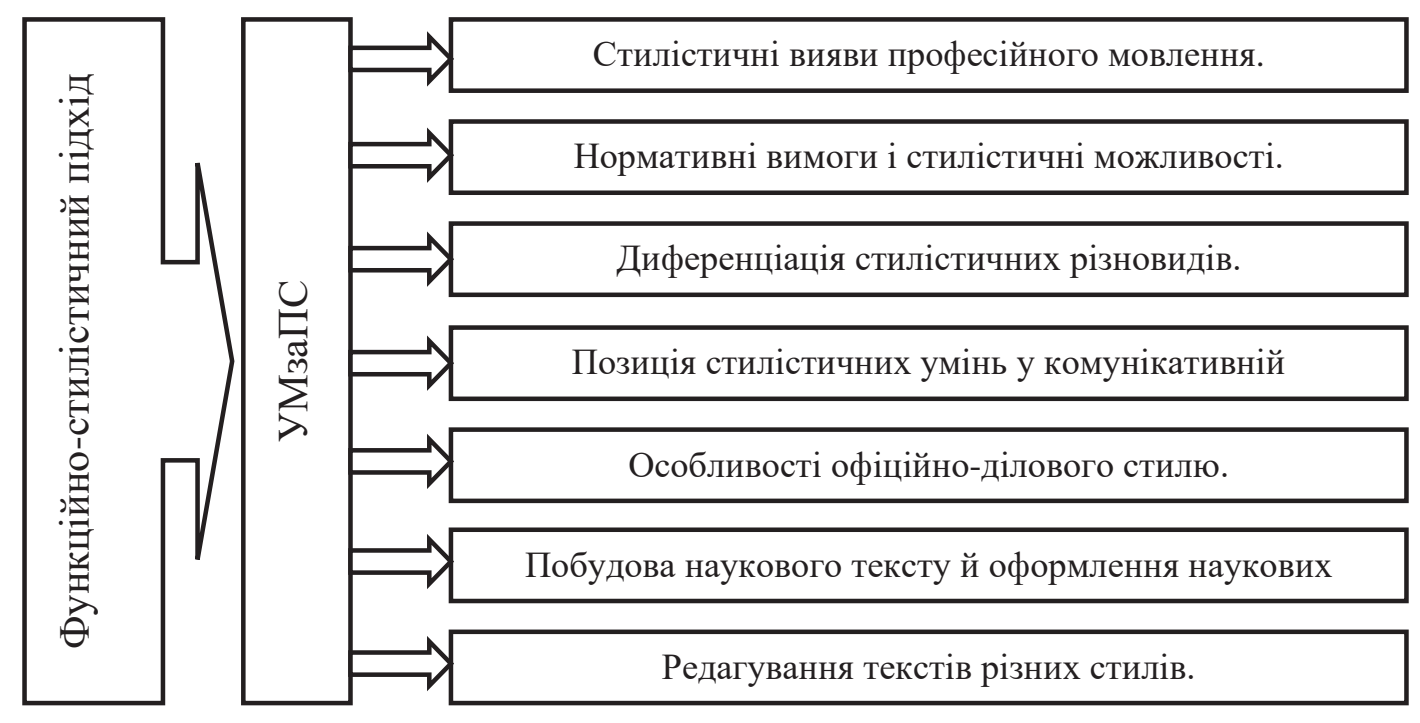

Рис. 1. Функційно-стилістичний підхід до навчання УМзаПС Джерело: розроблено автором 
тів. Його відповідність вимогам конкретизується порівняно 3 елементами розмовно-побутового та просторічного стилів, що трапляються у студентському мовленні. Щодо емоційно-експресивних стилів, то стрижневим аспектом є засвоєння студентами комунікативних ситуацій (відповідно до стильової приналежності), у яких недопустимі ознаки експресії (науковий, офіційно-діловий контекст), та розуміння етичної міри вияву цих ознак у публіцистичному, художньому, епістолярному чи розмовному контекстах.
Висновки. Таким чином, процес реалізації функційно-стилістичного підходу до мовної освіти у курсі УМзаПС спрямований на формування професійно-мовленнєвої компетентності студентів, спирається на лінгвістичну основу, охоплює теоретико-прикладну роботу з усіма стилістичними різновидами писемного, усного й емоційно-експресивного мовлення, передбачає поетапну системну діяльність щодо нормативного використання мовних засобів усіх рівнів зі стилістичною метою.

\section{ЛІТЕРАТУРА}

1. Гуменюк I. М. Ретроспективний аналіз змісту навчання української мови за професійним спрямуванням. Гірська школа Українських Карпат. 2020. № 22. С. 60-66.

2. Державний стандарт початкової освіти. Постанова Кабінету Міністрів України від 24 липня 2019 р. № 688. URL: https://zakon.rada.gov.ua/laws/show/87-2018-\%D0\%BF\#n12 (дата звернення: 07.09.2021).

3. Левківська О. А. Система вправ із вивчення мовних норм та їхніх стилістичних варіантів у курсі української мови професійного спрямування для студентів нефілологічних спеціальностей ВНЗ. Шляхи вдосконалення мовної компетениії сучасного педагога (Матеріали регіональної науково-методичної конферениії, 27 березня 2008 p.). 2008. C. 59-63.

4. Нечипоренко А. Формування стилістичної компетентності здобувачів вищої освіти на заняттях з «Української мови за професійним спрямуванням». Українська мова та культура в сучасному гуманітарному часопросторі: аспекти формування комунікативної компетентності фахівия. Збірник матеріалів міжнародної науковопрактичної конференції. 19 лютого 2021 р. Ірпінь. С. 107-110.

5. Про затвердження професійного стандарту за професіями «Вчитель початкових класів закладу загальної середньої освіти», «Вчитель закладу загальної середньої освіти», «Вчитель з початкової освіти (з дипломом молодшого спеціаліста)». Наказ Міністерства розвитку економіки, торгівлі та сільського господарства України № 2736 від 23 грудня 2020 p. URL: https://nus.org.ua/ wp-content/uploads/2020/12/Nakaz_2736.pdf (дата звернення: 07.09.2021).

6. Серебрянська I. М. Стилістичні особливості та культура ділової усної комунікації. Вісник Сумського державного університету. Серія Філологічні науки. 2007. № 1. Т. 1. С. 166-172.

7. Шевчук С. В., Клименко І. В. Українська мова за професійним спрямуванням : підручник. Київ : Алерта, 2010. $696 \mathrm{c}$.

\section{REFERENCES}

1. Humeniuk, I. M. (2020). Retrospektyvnyi analiz zmistu navchannia ukrainskoi movy za profesiinym spriamuvanniam. [Retrospective analysis of the content of teaching Ukrainian language for professional purposes]. Hirska shkola Ukrainskykh Karpat, 22, 60-66. [in Ukrainian].

2. Derzhavnyi standart pochatkovoi osvity. Postanova Kabinetu Ministriv Ukrainy vid 24/07/2019. № 688. [State standard of primary education. Resolution of the Cabinet of Ministers of Ukraine of July 24, 2019 № 688]. Available at: https://zakon.rada.gov.ua/laws/show/87-2018-\%D0\%BF\#n12 (Last accessed: 07.09.2021). [in Ukrainian].

3. Levkivska, O. A. (2008). Systema vprav iz vyvchennia movnykh norm ta yikhnikh stylistychnykh variantiv u kursi ukrainskoi movy profesiinoho spriamuvannia dlia studentiv nefilolohichnykh spetsialnostei VNZ. [The system of exercises for the study of language norms and their stylistic variants in the course of the Ukrainian language of professional orientation for students of non-philological specialties of higher education]. Shliakhy vdoskonalennia movnoi kompetentsii suchasnoho pedahoha. Zbirnyk materialiv, 27 bereznia 2008, 59-63. [in Ukrainian].

4. Nechyporenko, A. (2021). Formuvannia stylistychnoi kompetentnosti zdobuvachiv vyshchoi osvity na zaniattiakh z "Ukrainskoi movy za profesiinym spriamuvanniam". [Formation of stylistic competence of higher education students in classes on "Ukrainian language for professional purposes"]. Ukrainska mova ta kultura v suchasnomu humanitarnomu chasoprostori: aspekty formuvannia komunikatyvnoi kompetentnosti fakhivtsia. Zbirnyk materialiv mizhnarodnoi naukovo-praktychnoi konferentsii. 19.02.2021. Irpin. 107-110. [in Ukrainian].

5. Pro zatverdzhennia profesiinoho standartu za profesiiamy "Vchytel pochatkovykh klasiv zakladu zahalnoi serednoi osvity" "Vchytel zakladu zahalnoi serednoi osvity", "Vchytel z pochatkovoi osvity (z dyplomom molodshoho spetsialista)". [About the statement of the professional standard on professions "The teacher of initial classes of establishment of general secondary education", "The teacher of establishment of general secondary education", "The teacher on primary education 
(with the diploma of the junior specialist)"]. Nakaz Ministerstva rozvytku ekonomiky, torhivli ta silskoho hospodarstva Ukrainy № 2736 vid 23.12.2020. Available at: https://nus.org.ua/wpcontent/uploads/2020/12/Nakaz_2736.pdf (Last accessed: 07.09.2021). [in Ukrainian].

6. Serebrianska, I. M. (2007). Stylistychni osoblyvosti ta kultura dilovoi usnoi komunikatsii. [Stylistic features and culture of business oral communication]. Visnyk Sumskoho derzhavnoho universytetu. Seriia: Filolohichni nauky, 1, T. 1, 166-172. [in Ukrainian].

7. Shevchuk, S. V., Klymenko, I. V. (2010). Ukrainska mova za profesiinym spriamuvanniam: Pidruchnyk. [Ukrainian language for professional purposes: Textbook]. Kyiv: Alerta. [in Ukrainian].

\section{M. HUMENIUK}

Ph.D. in Philology, Associate Professor,

Associate Professor at the Department of Pedagogy of Primary Education,

Vasyl Stefanyc Precarpathian National University,

Ivano-Frankivsk, Ukraine

E-mail:imix@ukr.net

http://orcid.org/0000-0002-0790-6732

\section{THE FUNCTIONAL AND STYLISTIC APPROACH \\ TO TEACHING UKRAINIAN LANGUAGE FOR PROFESSIONAL PURPOSES TO FUTURE PRIMARY SCHOOL TEACHERS}

The article focuses on studying the problem of implementation of the functional and stylistic approach in the context of teaching the Ukrainian Language for Professional Purposes discipline. On the basis of retrospective analysis of evolutionary changes in the content of the discipline and the specificity of the professional activity of a primary school teacher, the use of the functional and stylistic approach has been substantiated with an emphasis on the peculiarities of each style in a corresponding communicative situation. The author elaborates the phased implementation of the functional and stylistic approach to teaching Ukrainian Language for Professional Purposes, which envisages adherence to the principles of systematicity and gradualism, scientificity, and complexity increase, as well as ensuring the professional context in the educational activity and the connection between theory and practice. Every determined stage has been analysed with regard to the efficient forms of organisation of students' work, task complexes, and the products of educational activity that are assessed. The motivational, activity-related, and applied aspects of stylistic work have been elaborated. The necessity of consideration of the normative framework, particularly the professional standard of the "Primary school teacher at a general secondary education institution" profession, the State Standard of Primary Education, and the active DSTU 4163-2003 has been emphasized. It has been noted that implementation of the analysed approach is conducted in the process of mastering the written and spoken, as well as emotional and expressive styles of the Ukrainian language. For application of the functional and stylistic approach to formation of the scientific speech of future pedagogues, interdisciplinary integration is needed, which contributes to the complex vision of the communicative environment in the professional sphere.

Key words: language education, professional speech, style, term, competence, stylistic editing, functional and stylistic approach. 